\title{
Avaliação da sazonalidade do mercado de flores e plantas ornamentais no Estado de São Paulo ${ }^{1}$
}

\author{
ROBERTA WANDERLEY DA COSTA MARQUES ${ }^{2}$ \\ e JOSÉ VICENTE CAIXETA FILHO ${ }^{3}$
}

\begin{abstract}
RESUMO
O presente trabalho teve como objetivo precípuo a avaliação do comportamento sazonal dos volumes e preços praticados na floricultura paulista. Para tanto, houve necessidade de seleção dos produtos e entrepostos a serem trabalhados. Os produtos escolhidos foram: rosa, crisântemo e violeta. Dados referentes à década dos noventas foram levantados em entrepostos de comercialização selecionados no Estado de São Paulo, a saber: Companhia de Entrepostos e Armazéns Gerais de São Paulo (CEAGESP-SP), Veiling Holambra (cooperativa que comercializa produto de produtores via leilão eletrônico) e a Central de Abastecimento S.A de Campinas (CEASA-Campinas). Além desse objetivo, realizou-se a identificação dos períodos sazonais existentes, a identificação das características do comportamento sazonal de volumes e preços e a comparação das características de mercado das principais flores e plantas ornamentais comercializadas nos entrepostos selecionados paulistas. Os resultados do trabalho apontaram períodos diferentes para o volume de rosa, crisântemo e violeta. Por outro lado, para cada tipo de flor, observaram-se maiores semelhanças para o período de preços adotados nesses entrepostos. Por exemplo, o período 12 foi encontrado para os preços praticados para rosas nos três entrepostos, isto é, existem picos de preços de 12 em 12 meses em cada um deles. Observaram-se, também, grandes ligações entre as datas festivas e os períodos encontrados, tanto para volumes quanto para preços. Portanto, tal como para a maior parte dos produtos agrícolas, informações a respeito do período sazonal também são de extrema importância ao sistema de comercialização de flores e plantas ornamentais. Tanto produtores como consu-
\end{abstract}

midores podem-se beneficiar a partir do conhecimento do comportamento mais sistemático que seus produtos de interesse revelam. Conhecendo os picos sazonais de comercialização, o produtor pode organizar sua produção de tal forma que novas oportunidades de negócio sejam configuradas a partir de uma melhor e maior distribuição de picos ao longo do ano. Com um número maior de picos de comercialização durante o ano, a receita anual, além de incrementada, será mais bem distribuída ao longo do período.

Palavras-chave: sazonalidade, flores, plantas ornamentais.

\section{ABSTRACT \\ Seasonality's evaluation of flowers and ornamental plants market in the State of São Paulo, Brazil}

This dissertation has the main objective to evaluate an eventual seasonal behavior of volumes and price series at floriculture in the State of São Paulo, Brazil. For this reason, a selection of products and trade centers was necessary. The chosen products were: rose, chrysanthemum and violet. Data refering to the decade of 1990 were got from the trade centers selected in the State of São Paulo: CEAGESPSP - "Companhia de Entrepostos e Armazéns Gerais de São Paulo"; Veiling Holambra - a cooperative which trades directly from producers through eletronic auction - and CEASA-Campinas - a permanent market of flowers in Campinas. Apart from this principal aim, the identification and characterization of the seasonal period of volumes and prices, and the comparison of market characteristics of main

\footnotetext{
${ }^{1}$ Pesquisa com apoio da FAPESP.

2 Assistente de Pesquisa do IPEA- RJ. Av. Pres. Antônio Carlos, 51, 15º andar, 1522. Centro, 20020-010 Rio de Janeiro (RJ). E-mail: robertam@ipea.gov.br

${ }^{3}$ Professor Associado, Doutor, Departamento de Economia, Administração e Sociologia da ESALQ-USP. E-mail: jvcaixet@esalq.usp.br
} 
flowers and ornamental plants traded in the selected facilities in the State of São Paulo were made. The results of the research pointed distinct periods for the volumes and presented similarity for the price periods. For example, the period of 12 months was found to the price of rose in every trade center. Moreover, it was observed that there are links between commercial dates and the found periods for volumes and prices. Therefore, like for the most agricultural products, it is believed that information about seasonal periods is extremelly important for the trade system of each product. With this knowledge, both, producers and consumers, can benefit themselves. Knowing the seasonal periods, producers can organize their production to make it meet consumers' demand; consequently, they can create more peaks during the whole year. Increasing the trade peaks, the anual revenue also increases being better distributed during the period.

Key-words: seasonality, flowers, ornamental plants.

\section{INTRODUÇÃO}

A floricultura, em seu amplo sentido, abrange o cultivo de flores e plantas ornamentais com variados fins, incluindo desde as culturas de flores para o corte à produção de mudas arbóreas.

Além dos seus valores emocionais, LESZCZYÑSKA-BORYS \& BORYS (1994) comentam sobre os valores que as flores e plantas ornamentais representam, tais como: valores estéticos e intelectuais, dados por sua arquitetura, suas cores e muitas vezes seu perfume; valores medicinais; ecológicos, dados por sua capacidade de purificação do ar, do solo e da água; e valores econômicos, podendo ser utilizadas como enfeites, adornos em jardins, presentes e matéria-prima para perfumes, cosméticos e remédios.

$\mathrm{O}$ ambiente institucional influencia todos os atores do Complexo Agroindustrial das Flores (CAF), desde os fornecedores de insumos até os consumidores finais. Segundo CLARO (1998), o agregado dos fornecedores de insumos é formado por laboratórios e empresas fornecedoras de mudas. Esse primeiro agregado possui estreita relação com o da produção. Já as ligações do agregado da produção com o da distribuição ocorrem por vias diretas com floriculturas e, na grande maioria, via estruturas de comercialização, entre elas as Centrais de Abastecimento S/A (CEASAs) e o Veiling Holambra, centro de comercialização que é parte integrante da Cooperativa Agropecuária Holambra (SP).
Tais centros são responsáveis pela venda de produtos aos distribuidores, a partir de normas e regras próprias.

Vale também destacar que o Brasil possui notórias vantagens para especializar-se na produção de flores, como o clima, a disponibilidade de terra, água, energia e mão-de-obra. Além disso, a rentabilidade dos negócios da floricultura reforça a capacidade de crescimento do setor. Segundo KÄMPF et al. (1990), a floricultura nacional é uma atividade agrícola que requer pequena área de cultivo, permitindo o aproveitamento de áreas marginais da agricultura tradicional. Assim, além de possibilitar um alto rendimento por área cultivada, pode constituir uma fonte alternativa de renda para pequenos proprietários, localizados próximos a centros comerciais.

É importante observar também casos de países como a Holanda, competitiva internacionalmente em termos de custos, e que, segundo GROOT (1998), não depende de baixos custos de mão-de-obra, terra, matéria-prima e capital, mas, sim, da sua capacidade de inovar rapidamente. E isso, claramente, se reflete em produtividade, qualidade, mão-de-obra altamente profissionalizada e alta tecnologia.

A localização da produção e dos centros de comercialização é fator importante nessa atividade agrícola. Conforme KRAS (1998), 90\% da produção e do consumo de flores e plantas ornamentais se dá em um raio de $500 \mathrm{~km}$ entre eles, dado que os custos de transporte e de distribuição de produtos altamente perecíveis limitam as distâncias para comercialização.

De modo geral, a comercialização e distribuição de flores e plantas ornamentais se dá através de centrais de comercialização. Segundo CASTRO (1998), existem centrais onde somente entram benefícios de produtores, como é o caso do Veiling Holambra e do Mercado do Profissional da Floricultura e do Paisagismo (Mercaflor-SC); existem também aquelas onde entram produtos de fornecedores e atacadistas, como a CEAGESP-SP e a CEASA-Campinas e, ainda, aquelas onde somente se comercializam produtos de atacadistas, como a Companhia de Abastecimento do Estado da Guanabara (CADEG-Rio de Janeiro) e a CEASA-Porto Alegre.

Em se tratando do Estado de São Paulo, os principais centros se resumem ao Veiling Holambra, à CEAGESP-SP e à CEASA-Campinas.

CLARO \& OLIVEIRA (1999) relatam que o Veiling Holambra é uma unidade da Cooperativa Agropecuária Holambra, responsável por $40 \%$ da 
comercialização nacional em 1997, operando um sistema de venda por pregão diário. O Veiling conta com uma forte preocupação com a padronização e com normas de qualidade e atende, principalmente, a atacadistas e floriculturas.

ARRUDA et al. (1996), ao comentarem sobre o mercado de flores da CEAGESP-SP, localizado na capital paulista, destacam que tal entreposto concentra a produção de várias regiões, facilitando a atividade dos compradores. Todavia, a falta de padrões de classificação e o longo período de comercialização prejudicam a aparência dos produtos, atributo essencial para a comercialização de flores.

Já a CEASA tem um de seus principais entrepostos localizado em Campinas, no interior do Estado de São Paulo, próximo às principais regiões produtoras. CASTRO (1998) acredita que, sobretudo, devido a esse fato, a CEASA-Campinas vem-se revelando como alternativa à comercialização até então predominante na CEAGESP-SP.

Em pesquisa realizada pelo IBRAFLOR, em 1995, publicada por ARRUDA et al. (1996), constatou-se que $53 \%$ da comercialização de flores no Brasil é realizada pela CEASA-Campinas e pela CEAGESP-SP.

Atualmente, a alternativa para a comercialização de flores e plantas ornamentais é o uso da Internet. Segundo BONGERS (2001), a comercialização eletrônica traz comodidade ao consumidor e apoio aos produtores e comerciantes. No Brasil, existem algumas empresas já operando no sistema de comercialização via Internet.

BONGERS (2001) cita a implantação do Sistema Eletrônico de Comercialização - CEASA Virtual - onde a CEASA-Campinas pretende incentivar a modernização efetiva do segmento atacadista da comercialização de hortigranjeiros, com reflexos positivos nas demais etapas da cadeia produtiva, viabilizando a diminuição de custos de comercialização e o aperfeiçoamento geral de frutas, hortaliças e flores. Entre outros sistemas, o autor acrescenta empresas como a FloraNet, que utiliza basicamente a Internet como veículo de comunicação com o mercado e que tem um sistema de comercialização eletrônica que opera em tempo real de forma dinâmica e iterativa.

Segundo GROOT (1998), o consumo de flores de corte no mundo em 1985 foi de, aproximadamente, 12,5 bilhões de dólares. Em 1990, o consumo cresceu para 25 bilhões de dólares e, em 1995, já chegava a 31 bilhões.

Vários autores ressaltam que o Brasil possui uma demanda sazonal por flores e plantas ornamentais.
Segundo ALMEIDA \& AKI (1995), o pioneirismo do cultivo comercial deveu-se à colônia portuguesa, cuja produção atingia o mercado em datas comemorativas, ou seja, em épocas de maior demanda, a saber: Dia das Mães, Finados e Natal. CLARO (1998) complementa que outras datas fortes acabaram por ser inseridas no calendário: Dia Internacional da Mulher, Dia dos Namorados, Dia das Avós, Dia dos Pais, Dia das Secretárias etc. CASTRO (1998) observa que o mercado consumidor de flores diminui significativamente no período de férias escolares.

Outro fato interessante diz respeito à característica cultural associada a esse tipo de mercado no Brasil. Acreditando que comprar flores para enfeitar a casa no dia-a-dia não seja um hábito comum para os brasileiros, BARLETTA (1995) estima que de 3 a 4\% dos consumidores brasileiros compram flores, observando-se em 1994 uma média de despesas de US\$4.00 per capita com flores. CASTRO (1998) acredita que esse valor médio chegou a US\$7.00 per capita em 1998, mas, mesmo assim, muito inferior ao consumo observado em outros países. Outros autores, como KIYUNA (1998), acreditam que esses valores tenham passado de US\$3.00 para US\$6.00 per capita, entre 1994 e 1998. No Brasil, apenas o Rio Grande do Sul se destaca como grande centro consumidor, com uma média per capita próxima à da Argentina (US\$20,00/ano), segundo CASTRO (1998).

Apesar da demanda irregular e da falta de incentivo ao consumo de flores, espera-se que esse quadro possa modificar-se. Segundo CASTRO (1998), o consumo tende a crescer no segmento do "uso próprio", além de continuar seu avanço pelo interior do País. Expansão ainda maior será verificada com a entrada na linha de supermercados, onde se cria uma demanda quase constante durante o ano, quebra-se a sazonalidade e o produtor passa a investir mais na continuidade.

SANTIAGO et al. (1996) acrescentam que o mercado de produtos agrícolas caracteriza-se por apresentar maior grau de sensibilidade no que se refere a oscilações de preços comparativamente ao mercado de bens industriais. Isso se deve ao fato de que as características intrínsecas que regem as condições de produção do mercado agrícola, não somente proporcionam elevado grau de instabilidade como, também, grande amplitude de variação dos preços de seus produtos.

Acredita-se que se o crescimento econômico continuar ocorrendo em países da América Latina, será observado também um aumento na demanda de flores e plantas ornamentais. Segundo GROOT (1998), o cres- 
cimento no consumo de flores de corte é altamente dependente do desenvolvimento econômico de diferentes países no mundo e do incremento da "cultura" em consumir flores.

Autores como GROOT (1998) e KRAS (1998) acreditam que a demanda por flores no mundo, nos próximos anos, tende a aumentar, e que a produção crescerá mais rapidamente que o consumo, o que perpetuaria uma competição por melhores preços. Outros autores, como SALUNKHE et al. (1990), acreditam, também, que a demanda dos consumidores por flores e plantas ornamentais sempre irá exceder a produção e que seu mercado terá uma expansão cada vez mais rápida à medida que forem incorporados métodos mais eficientes de marketing.

Entretanto, os métodos de marketing terão maior chance de sucesso se consumidores estiverem efetivamente satisfeitos com a qualidade das flores e plantas ornamentais a serem adquiridas. Infelizmente, no Brasil, grande parte da produção é perdida logo após a saída do produto do local de cultivo. Tais perdas atingem cifras muitas vezes superiores a $40 \%$, segundo estudo realizado em 1984 por CASTRO (1985). Para minimizar tais perdas, SONEGO \& BRACKMANN (1995) sugerem a necessidade urgente de desenvolvimento e uso de técnicas que prolonguem a durabilidade das flores, mantendo a qualidade do produto e reduzindo as perdas pós-colheita.

Ainda, tratando-se da qualidade de flores e plantas ornamentais, OLIVEIRA (1995) destaca que, muitas vezes, o produto é visualmente aceito quando vendido; entretanto, tem vida curta, o que irá resultar em perda adicional de satisfação pelo consumidor. Tal constatação corrobora o fato de que a distribuição de flores pode e deve ser melhorada para aprimorar as vendas e incrementar o consumo.

As ineficiências do setor de distribuição não contribuem para a melhoria das relações entre os consumidores brasileiros e as flores e plantas ornamentais, ou seja, com tantas dificuldades, o consumo se concentra em certas datas do ano, retardando ainda mais as tentativas de não somente aumentar o consumo, mas, também, distribuí-lo melhor ao longo do ano.

MATSUNAGA (1995) salienta ainda que a sazonalidade de produção de flores dificulta a comercialização. Uma solução de caráter técnico seria implantação de estufas climatizadas para viabilizar uma produção contínua, de forma a uniformizar a oferta de produto que, como resultado, refletiria em uma demanda permanente de mercado.
Existem dois interesses principais no ajustamento sazonal, de acordo com PIERCE (1980): o estudo da sazonalidade propriamente dita e a remoção da sazonalidade da série para depois estudá-la em seus demais aspectos.

PINO et al. (1994) ressaltam que as causas da sazonalidade podem estar reunidas em dois grandes grupos: as provocadas, direta ou indiretamente, pela existência das estações do ano; e as relacionadas ao calendário. Essas últimas se devem aos fatores culturais, podendo afetar variáveis como a demanda por certos produtos em determinadas épocas do ano, o que pode ocorrer, por exemplo, com as flores.

Segundo o mesmo autor, a sazonalidade relacionada ao calendário pode ser causada em variáveis tipo fluxo quando ocorre variação do número de dias do mês. De acordo com GRANGER (1978), decisões institucionais ou individuais sobre o uso do tempo, como é o caso de férias escolares, final de ano fiscal etc., e também as expectativas podem gerar um padrão sazonal, como, por exemplo, a produção de brinquedos, na expectativa de maiores vendas durante o período natalino.

Em vista da importância do planejamento para a comercialização e consumo de produtos agrícolas, o conhecimento das variações estacionais dos preços, por exemplo, fornece subsídios aos produtores para alocação temporal mais eficiente. Além disso, pode servir para orientar o consumidor sobre as principais épocas de compra, melhorando a eficiência da utilização de sua renda.

ALONSO et al. (1997) apontam que, infelizmente, as pesquisas focadas no segmento de flores e plantas ornamentais não têm prioridade nem em órgãos especializados. Em pesquisa realizada em jardins botânicos de todo o mundo, em 1990 , somente $25 \%$ deles possuíam profissionais especializados em pesquisa de flores e plantas ornamentais e apenas $9 \%$ davam a devida importância a essas linhas de pesquisa.

CASTRO (1998) enfatiza que as pesquisas no setor visam à solução de problemas referentes ao cultivo e comercialização de espécies com grande potencial comercial sobre as quais, em sua maioria, existem insuficientes informações.

Em se tratando do estudo da demanda de flores, pode-se citar o trabalho, realizado por ALBERTINI et al. (1999), analisando a variação no volume de entrada de flores nas principais datas festivas na CEAGESPSP em 1998. Esse estudo resumia-se à identificação dos volumes de flores que chegavam à CEAGESP-SP, duas semanas antes e duas semanas depois de datas festivas selecionadas. 
No Brasil, também, foi encontrado um estudo da variação estacional da oferta de algumas flores comercializadas em trabalho publicado por GATTI (1988). Esse autor realizou um estudo sobre a situação da floricultura até 1988 e observou comportamentos sazonais, de acordo com as datas festivas, para a oferta de produtos selecionados, entre eles: rosas, crisântemos, gladíolos, antúrios, cravos e orquídeas.

Encontraram-se pesquisas em outros países a respeito da demanda de flores, como o trabalho de CHONMALUCK (1996), que procurava analisar as elasticidades preço e renda, a fim de guiar a Tailândia a adotar estratégias mais corretas para a exportação de orquídeas. Esse autor acreditava, com isso, poder melhorar a diversificação da agricultura e obter um aumento nos ganhos com exportação.

TAKIZAWA (1990), analisando a função demanda por plantas ornamentais no mercado atacadista em Tóquio, no Japão, obteve, por exemplo, resultados sobre a flexibilidade de preços, a qual se demonstrou maior para as flores de corte que para as flores em vaso, sugerindo então medidas políticas de controle da produção de flores de corte. Destacou-se, ainda, no mesmo estudo, a alta influência pela renda, criatividade e hábito de consumo em cada função de demanda estimada.

Em outra pesquisa no Japão, KONO (1997), além de descrever a produção, distribuição e consumo de flores de corte, estimou uma função demanda da Gypsophila paniculata para analisar a formação de preços no atacado. Os resultados mostraram que o preço dessa flor de corte foi bastante explicado pelo grau de qualidade, quantidade e seu valor de mercado.

Assim sendo, ressalta-se a importância e a necessidade de estudos empíricos da sazonalidade do mercado de produtos agrícolas no Brasil, incluindo, nesse caso, flores e plantas ornamentais. A sazonalidade e os fatores que a influenciam, se bem conhecidos e avaliados, permitirão uma prospecção mais efetiva em torno de previsões de mercado.

Por outro lado, é claro que, mesmo levando-se em consideração o potencial de crescimento desse segmento de mercado, a demanda de flores e plantas ornamentais no Brasil é ainda bastante irregular, aparentemente concentrada nas datas festivas, o que certamente deve ser levado em consideração quando da análise e avaliação do comportamento dos agentes envolvidos nessa cadeia.

Além disso, em vista de tantas incertezas quanto à produção efetivamente aproveitada, ao potencial de mercado e às preferências do consumidor interno e externo, pesquisas com o intuito de explorar melhor tais temas serão de extrema valia para o desenvolvimento econômico deste setor da agricultura brasileira.

O presente trabalho tem como objetivo principal a avaliação do eventual comportamento sazonal dos volumes e preços praticados na floricultura. Para tal, dados referentes à década dos noventas foram levantados nos principais entrepostos de comercialização do Estado de São Paulo.

\section{MATERIAL E MÉTODOS}

Os dados a serem utilizados nesta análise referemse a volumes e preços mensais praticados para flores e/ ou plantas ornamentais selecionadas em determinados entrepostos, por determinado período.

Conforme observado na literatura, é consensual a importância de três entrepostos especializados na comercialização de flores e plantas ornamentais no Estado de São Paulo: a CEAGESP-SP, a CEASA-Campinas e o Veiling Holambra (unidade da Cooperativa Agropecuária Holambra), os quais foram selecionados para participarem como referências de dados para esta pesquisa.

Na CEAGESP-SP, parte dos dados foi obtida por meio de pesquisadores locais e parte foi coletada a partir do Boletim Mensal CEAGESP-SP (1992-2001), publicado pelo próprio entreposto, e tabulado em planilhas eletrônicas. Esses dados se referem aos volumes e aos preços mensais praticados no entreposto, especificados por produto, num período que se estende a um máximo de nove anos (1992 a 2001). Em vista da diversidade das informações e, muitas vezes, à irregularidade de coleta de dados por parte do próprio entreposto ou, ainda, à inserção de novas produções no mercado, os produtos possuem diferenças quanto ao período que abrange suas informações específicas.

De forma geral, os volumes mensais são informações mais sistemáticas que os preços mensais, ou seja, em muitos casos, obteve-se o volume em determinado período, mas não se obteve o preço correspondente a esse período. Por fim, optou-se por um período coincidente entre estes dois tipos de dados coletados.

Já na CEASA-Campinas e no Veiling Holambra, tais dados foram obtidos a partir de solicitação aos responsáveis pelos seus bancos de dados. Foram, assim, obtidos dados mensais de 1998 a 2001, no caso da CEASA-Campinas, e de 1995 a 2001, no do Veiling Holambra, abrangendo volumes e preços praticados das principais flores e plantas ornamentais comercializadas. 
Em virtude de uma diversificada e numerosa quantidade existente de flores e plantas ornamentais, deparou-se com a necessidade de escolha daquelas de grande representatividade no mercado desses produtos no Estado de São Paulo. Dessa forma, sua seleção foi realizada em função da importância que exercem em cada entreposto. Por fim, reuniram-se todas as informações pertinentes e escolheu-se aquelas correspondentes aos produtos que, de certa forma, eram os mais representativos para o Estado de São Paulo, a saber: rosas (cabo curto, médio e longo), crisântemos (em maço) e violetas (em caixas de pequenos vasos).

Para a detecção dos períodos de picos encontrados, utilizou-se o chamado periodograma. Após a identificação dos períodos, ajustou-se uma equação para cada uma das séries estudadas, a fim de identificar seu provável comportamento. Tais equações se basearam em modelos preconizados por BOX \& JENKINS (1976), sendo o software SAS (1999) uma ferramenta essencial para a detecção do período e ao ajuste dos modelos. Informações complementares a respeito dos modelos ajustados podem ser encontradas em NELSON (1973), ANDERSON (1976), JENKINS (1979) e BOX et al. (1994).

Em resumo, para tratamento dos dados de volumes e preços de cada um dos três produtos selecionados, em cada um dos três entrepostos, observou-se a seguinte seqüência de passos:

a) cálculo de regressão simples entre a média e o desvio-padrão da série, para que se identificasse o tipo de transformação (normalmente, logarítmica) adequada à homogeneização da variância dos resíduos;

b) com a série transformada, verificou-se a função de autocorrelação (FAC) e, em se percebendo a existência de tendência estocástica e de um eventual comportamento sazonal, realizou-se o teste de raiz unitária para checar a estacionariedade da série;

c) se a série possuía uma raiz unitária, uma diferença de ordem " 1 " era feita para eliminar a tendência estocástica existente;

d) após eliminar a eventual tendência estocástica, identificava-se o período de sazonalidade a partir do periodograma (normalmente com uma diferença), validando-se com o teste de periodicidade de Fisher;

e) para a escolha do melhor modelo que se ajustasse aos dados, as estimativas dos parâmetros, a variância, o desvio-padrão e o resultado da autocorrelação dos resíduos foram verificados e avaliados, a partir dos critérios de Akaike e Schwarz, do teste de Box e Pierce e dos resultados da função de autocorrelação (FAC) e da função de autocorrelação parcial (FACP) da série, com as devidas diferenças de ordens.

Neste artigo, pretende-se abordar principalmente as características dos volumes movimentados e preços de rosas, crisântemos e violetas nos principais entrepostos do Estado de São Paulo, destacando-se os períodos encontrados para cada produto. Entretanto, não é objetivo deste artigo abordar, com detalhes, as ferramentas metódicas e como se efetuaram as análises isoladas, atentando-se para os resultados obtidos e análises gráficas. Informações completas e maiores detalhes sobre os periodogramas podem ser encontradas em MARQUES (2002). Outros trabalhos publicados sobre o tema podem ser observados em MARQUES \& CAIXETA FILHO (2002a,b).

\section{RESULTADOS}

\subsection{Caracterização dos produtos selecionados em cada entreposto}

Na CEAGESP-SP, de 1995 a 1999, 51\% da receita dizia respeito à comercialização dos produtos escolhidos, sendo as rosas responsáveis por $30 \%$, os crisântemos em maço, por $17 \%$ e as violetas, por $4 \%$.

Tratando-se da CEASA-Campinas, esses produtos representaram, de 1998 a 2000, 27\% da receita, tendo os crisântemos em maço correspondido a $13 \%$, as rosas a $10 \%$ e as violetas a $4 \%$.

Entre os 22 produtos mais comercializados no Veiling Holambra, entre 1999 e 2000, as rosas por gerarem $22 \%$ da receita, as violetas $12 \%$ e os crisântemos em maço $10 \%$, totalizando $44 \%$ dos principais produtos comercializados nesse centro. Diante de tais estatísticas, pode-se notar que as rosas, os crisântemos e as violetas exercem, de fato, extrema importância no mercado de flores paulista.

\subsection{O mercado de flores nos entrepostos selecionados}

\subsubsection{CEAGESP-SP}

A CEAGESP-SP é um mercado onde prevalece a comercialização de produtos provenientes de produtores e atacadistas. As Figuras 1 e 2 apresentam, respectivamente, os volumes e os preços praticados nesse entreposto para rosas, crisântemos e violetas. Nota-se que, em termos de volume movimentado, as rosas ocupam o primeiro lugar e para os preços, a caixa de violetas atinge maior preço durante o período observado. 
O crisântemo comum foi a principal fonte de receita da CEAGESP-SP entre 1998 e 1999 e as rosas cortadas representam a segunda maior receita gerada por flores comercializadas para o mesmo período.

O volume de crisântemos, de outubro de 1993 a outubro de 1999, demonstra um comportamento crescente em grande parte do período, havendo quedas pontuais entre 1995 e 1996 e tendência decrescente a partir de 1997, verificando-se ainda que, em 1994, houve pouca oferta no mercado, com quedas em novembro.

Quanto ao comportamento dos preços para crisântemos, houve um aumento entre 1993 e 1994, tendendo a ficar mais estáveis entre 1998 e 1999. Em 1995 e 1997, verificou-se grande queda, com um ligeiro aumento de preços em fevereiro.

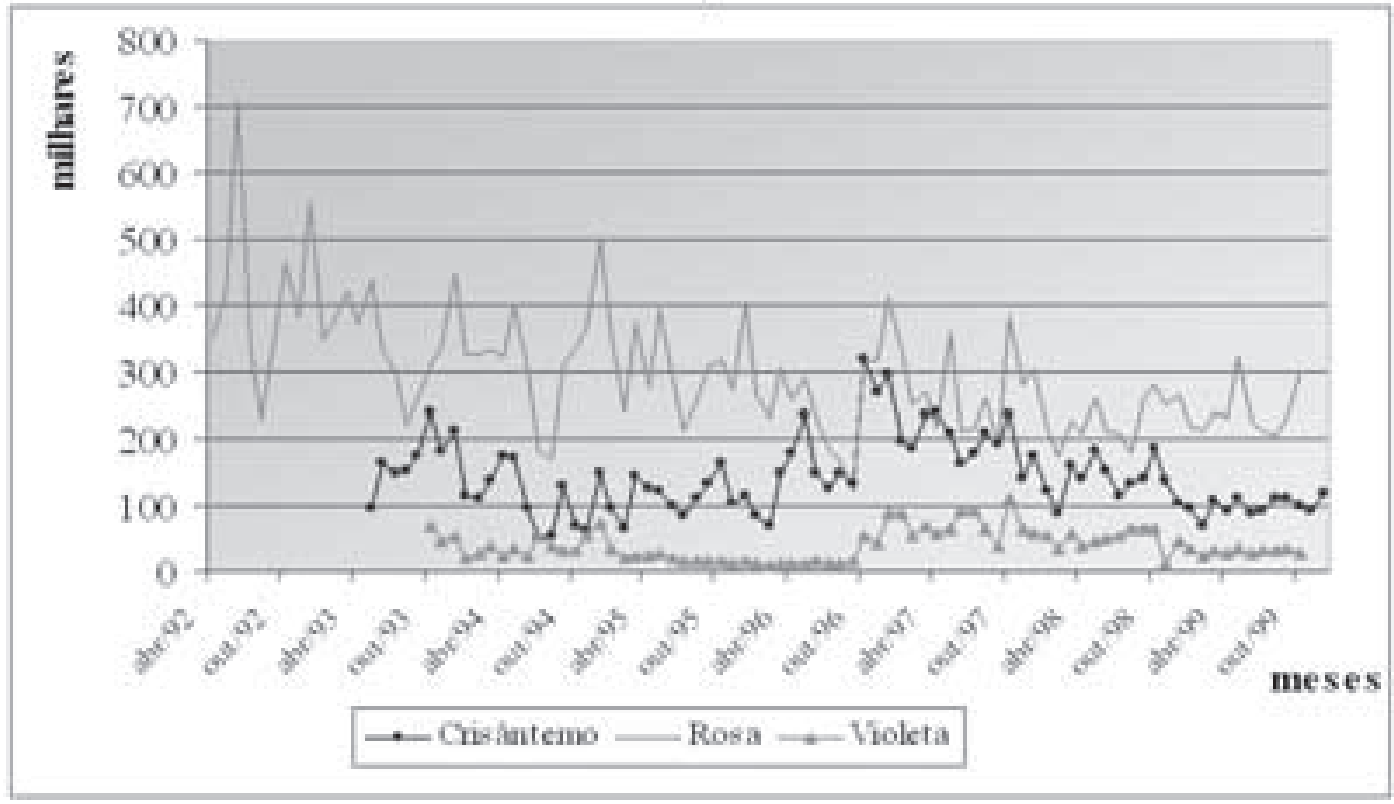

Figura 1. Volumes comercializados de rosas (em dúzias), crisântemos (em maços) e violetas (em caixas), na CEAGESP-SP, em períodos variados.

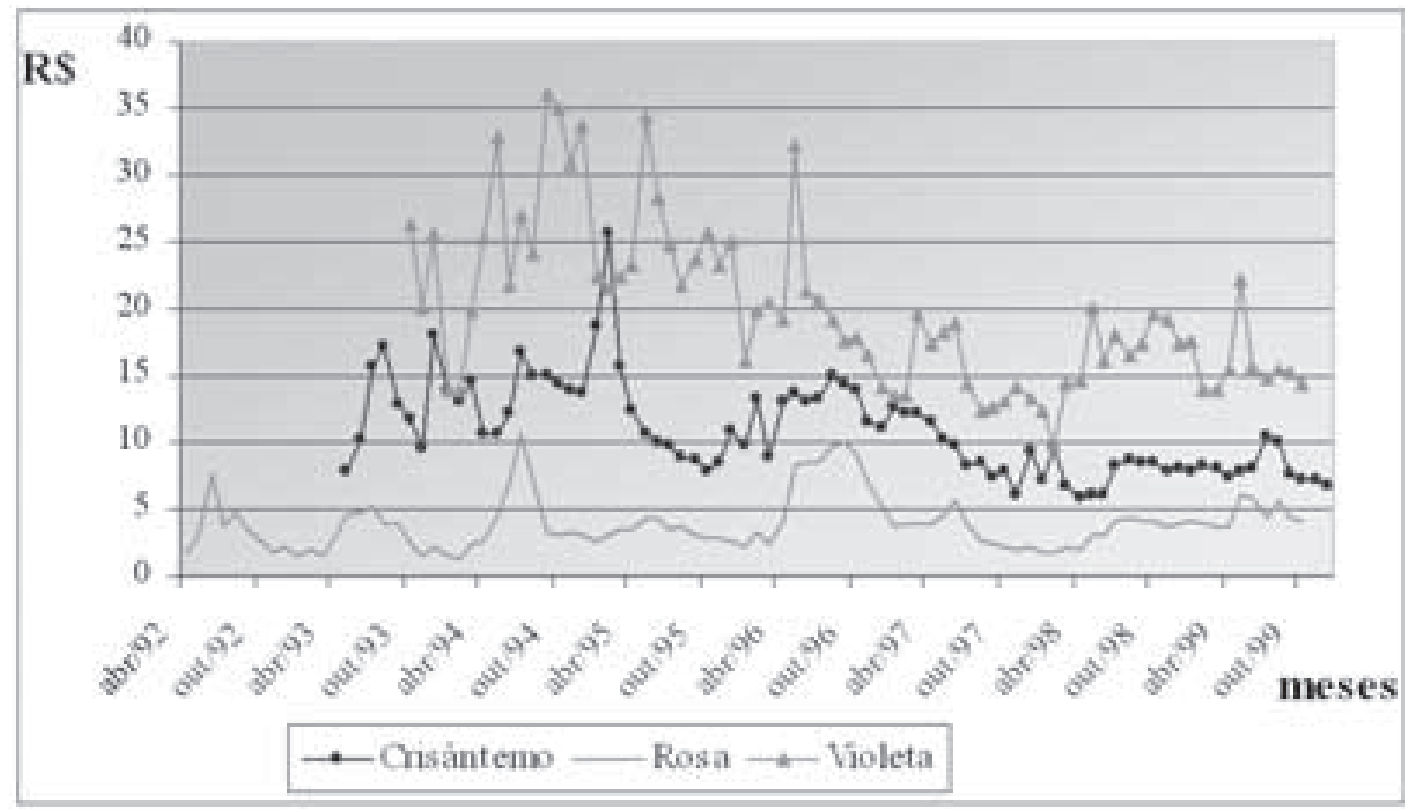

Figura 2. Preços praticados para rosas, crisântemos e violetas na CEAGESP-SP, em períodos variados. 
A comercialização de rosas na CEAGESP-SP, embora apresente grandes volumes mensais, vem diminuindo de abril de 1992 a outubro de 1999. Em se tratando do comportamento dos preços praticados mensalmente no mesmo período, observa-se um aumento em valores reais.

A diminuição do movimento de rosas deve-se, em parte, à competição com outras flores cortadas que surgiram no mercado ou até mesmo a preferência por flores envasadas, as quais têm como características, em sua maioria, maior durabilidade e praticidade em seu uso como arranjos. Pode-se citar, particularmente na CEAGESP-SP, que, entre suas flores e plantas ornamentais mais demandadas, houve aumento no volume comercializado de violetas, lírios, antúrios e gérberas para o mesmo período. Quanto ao comportamento desses dados, percebe-se que os preços observam picos em junho ou julho de cada ano, indicando um provável comportamento sazonal.

As violetas são flores altamente representativas no mercado de flores da CEAGESP-SP e são comercializadas neste local em pequenos vasos, que são vendidos em caixas de $6 \mathrm{~kg}$ (com 15 vasos aproximadamente). Sua comercialização, de 1994 a 2000, foi de cerca de 400 mil caixas anualmente.

$\mathrm{O}$ volume comercializado de violetas de outubro de 1993 a outubro de 1999 demonstra um comportamento crescente, havendo grande queda entre 1995 e 1996, particularmente em novembro. Quanto ao comportamento dos preços reais praticados no mesmo período, atenta-se para uma forte queda em 1996.

No tocante ao volume movimentado, os meses de maio, outubro e dezembro são igualmente importantes para rosas, crisântemos e violetas; para estas últimas, março revelou também uma data de pico de movimentação.

Na CEAGESP-SP, o volume de rosas e crisântemos possui período de pico de 6 em 6 meses, enquanto as violetas apresentam maior regularidade de procura durante o ano, com período de $3 \mathrm{em} 3$ meses. Quanto aos preços, seu período é de 6 meses para crisântemos e violetas e de 12 meses para as rosas.

Para todas as séries, os volumes e os preços em um período dependem, no mínimo, dos resultados do mês imediatamente anterior. Além disso, esses valores dependem, também, de sua própria variação sazonal, obedecendo a um ciclo que sofre influência direta em sua formação, conforme apresentado na seção anterior.

\subsubsection{Veiling Holambra}

Segundo CASTRO (1998), no Veiling Holambra são comercializados somente produtos de produtores cadastrados, mediante um pregão diário, fundamentado na concentração diária da oferta e da procura, possibilitando a realização do melhor negócio. As Figuras 3 e 4 representam o volume e os preços adotados para os três produtos escolhidos. Em termos de volume, as rosas e as violetas são as mais comercializadas, enquanto os crisântemos possuem um preço maior, visto, também, que os maços equivalem a duas dúzias.

As rosas cortadas representam a maior receita gerada por flores comercializadas no Veiling Holambra, seguidas por violetas e, depois, por crisântemos em maço entre 1999 e 2001. Nesse mesmo período, o entreposto movimentou, em média, 7 milhões de dúzias de rosas, 1,1 milhão de maços de crisântemos e cerca de 12 milhões de caixas de violetas anualmente.

A comercialização de rosas no Veiling Holambra manteve-se quase no mesmo patamar, a não ser em 1997 e 1998, quando se observou um aumento visível. Tratando-se do comportamento dos preços praticados mensalmente no mesmo período, verificaram-se valores reais mais altos em 1995 e 1996, seguidos de uma leve queda para manter-se praticamente constante até 2001. É detectado, também, um comportamento sazonal aparente, com picos altos em maio e/ou junho de cada ano.

Nota-se que o volume de crisântemos mantém uma variação semelhante de 1995 a 1998, diminuindo a partir de 1999 a quantidade comercializada de crisântemos. Quanto ao comportamento dos preços, nota-se uma variação maior entre 1995 e 1999, tendendo a variar menos entre 1999 e 2001. Os preços sofrem aumentos graduais no segundo semestre, chegando a seu maior pico no final do ano, de novembro a janeiro.

A comercialização de violetas é alta em 19992000, porém esse volume diminui se forem comparados os anos de 1995 a 1998. O comportamento dos preços reais, adotados no mesmo período, aponta uma clara diminuição no valor real, o qual se deveu principalmente ao aumento da escala de produção de violetas. Um aparente comportamento sazonal, com picos de aumento sobretudo em maio de cada ano, também pode ser notado.

Os volumes de rosas e violetas no Veiling Holambra observam período 3 , enquanto o volume de crisântemos e os preços de rosa possuem período 12. Para os preços de crisântemos e violetas, o período é de 6 meses. 


\subsubsection{CEASA-Campinas}

Esse mercado de flores, onde predominam transações envolvendo tanto atacadistas quanto varejistas, foi inaugurado em 1995 e, por esse motivo, a sua base de dados começou a ser implantada somente em 1998, quando sua movimentação já se mostrava mais consolidada. Nesse caso, segundo BOX et al. (1994), as séries de tempo com menos de 50 observações não são aconselhadas para esse tipo de análise, ou seja, as séries da CEASA-Campinas (no caso, constituídas por 38 ou 44 observações) participam deste trabalho como uma primeira tentativa de manusear estes dados, sem, contudo, possuir alta significância em seus resultados.

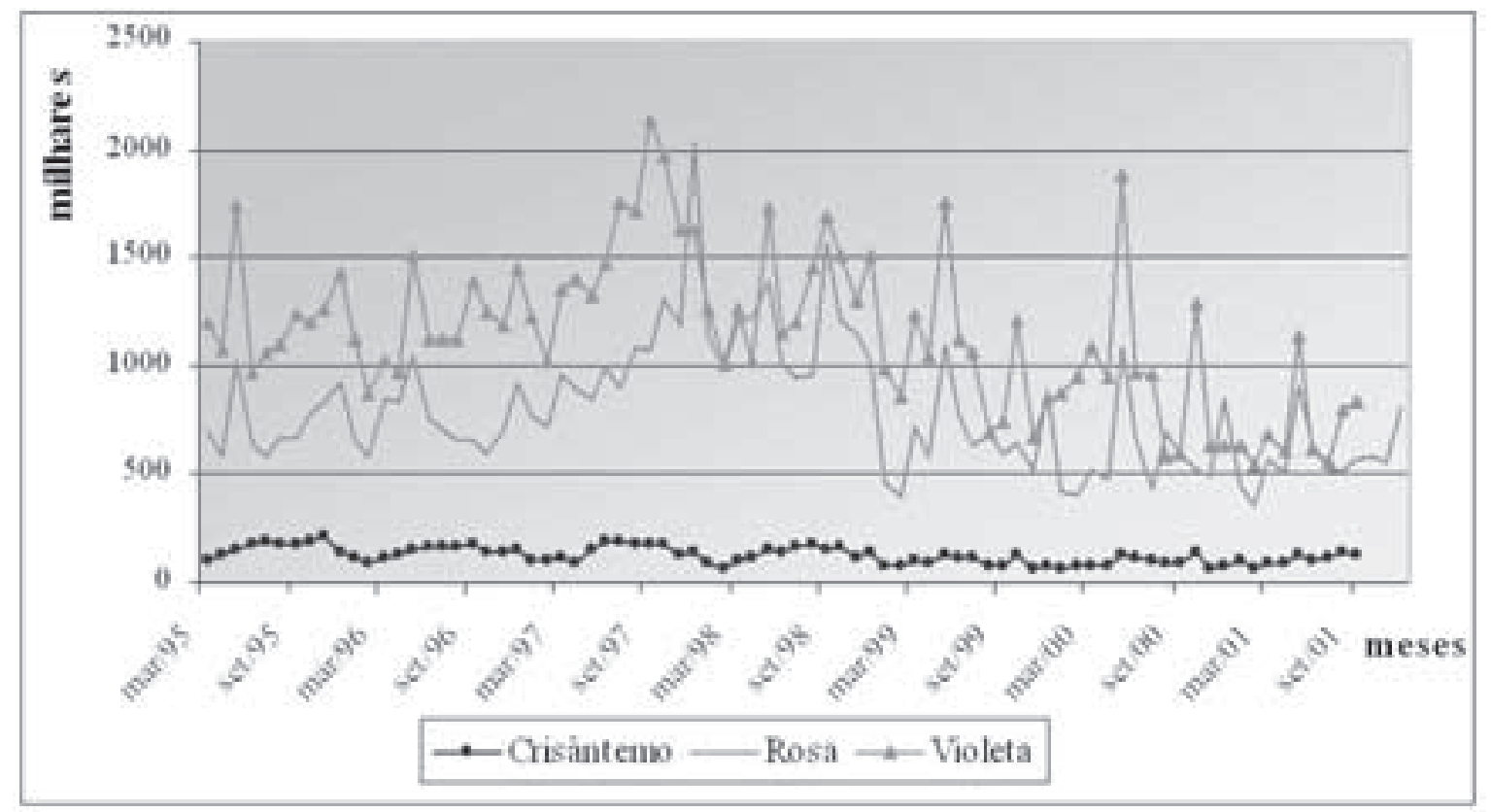

Figura 3. Volumes comercializados de rosas (em dúzias), crisântemos (em maços) e violetas (em caixas), no Veiling Holambra, em períodos variados.

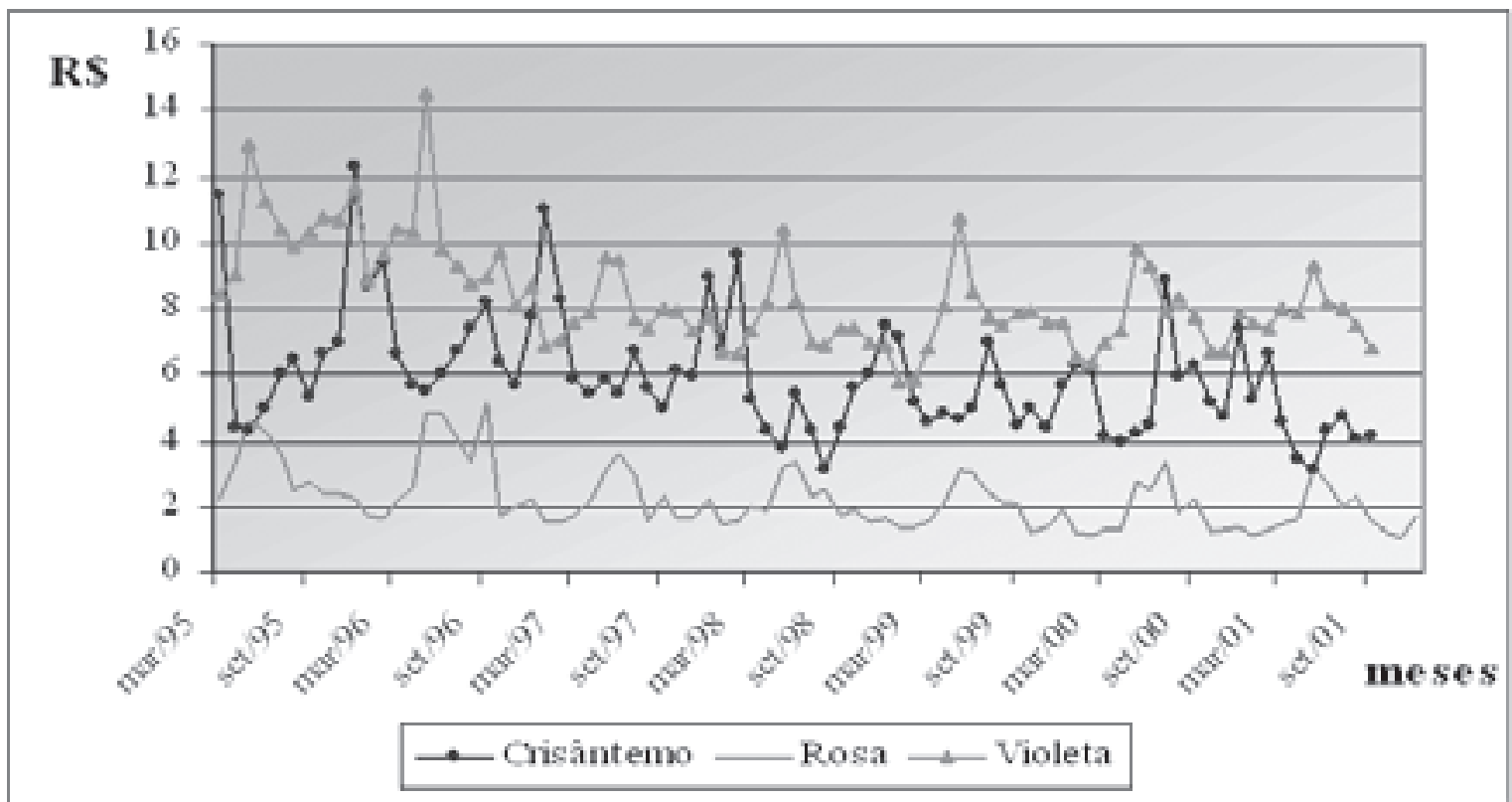

Figura 4. Preços adotados para rosas (por dúzia), crisântemos (por maço) e violetas (por caixa) no Veiling Holambra, em períodos variados. 
As Figuras 5 e 6 apresentam as séries de volume e preço, respectivamente, para rosas, crisântemos e violetas na CEASA-Campinas. Pode-se notar que as rosas são as mais comercializadas, em termos de volume; entretanto, são as violetas que atingem os preços mais altos.

A CEASA-Campinas movimentou, em média, 1,6 milhão de dúzias de rosas cortadas anualmente entre 1998 e 2000, consolidando-se como a segunda maior fonte de receita gerada no entreposto para o mesmo período. Apesar de o volume anual de crisântemos, de 1 milhão de maços entre 1998 e 2001, ser inferior ao de rosas para o mesmo período, o crisântemo foi a principal fonte de receita da CEASA-Campinas no período. As violetas também exercem papel importante na comercialização, representando o segundo maior volume de flores comercializadas em vaso e responsável por 5\% da receita total gerada nesse entreposto.

A comercialização de rosas aumentou de 1998 a maio de 2000, diminuindo a partir daquele mês até agosto de 2001, apresentando um aparente comportamento sazonal com picos em maio e dezembro. Em se tratando do comportamento dos preços praticados mensalmente no mesmo período, observa-se que, em valores reais, estes sofrem leves aumentos e sinalizam um comportamento sazonal com picos mais elevados principalmente em junho.
O volume de crisântemos aumenta gradativamente nesse período, explodindo em 2001. Sua movimentação também demonstrou um comportamento aparentemente sazonal, com picos elevados em maio, outubro e dezembro. Quanto aos preços, verifica-se uma queda de 1998 a meados de 2000, seguindo de uma irregularidade até o final do período.

Já para a movimentação de violetas, o volume demonstra um comportamento crescente entre 1998 e 1999, oscilando bastante a partir dessa data. Quanto ao comportamento dos preços reais, estes vêm diminuindo no mesmo período, devendo-se atentar para aumentos no seu valor real em maio.

De acordo com as análises conduzidas, o volume e os preços de rosas, crisântemos e violetas possuem períodos diferentes nesse entreposto. Para rosas e crisântemos, o período foi de 6 meses, enquanto, para violetas, foi de 11 meses, porém não significativo. Essa nãosignificância pode sugerir que, de acordo com essa série de dados, não seja possível detectar a periodicidade do volume de violetas. Já para os preços, o período para rosas foi de 12 meses, para crisântemos de 3 meses e para violetas de 6 meses. O preço de crisântemos também não foi significativo, indicando falha na detecção do período.

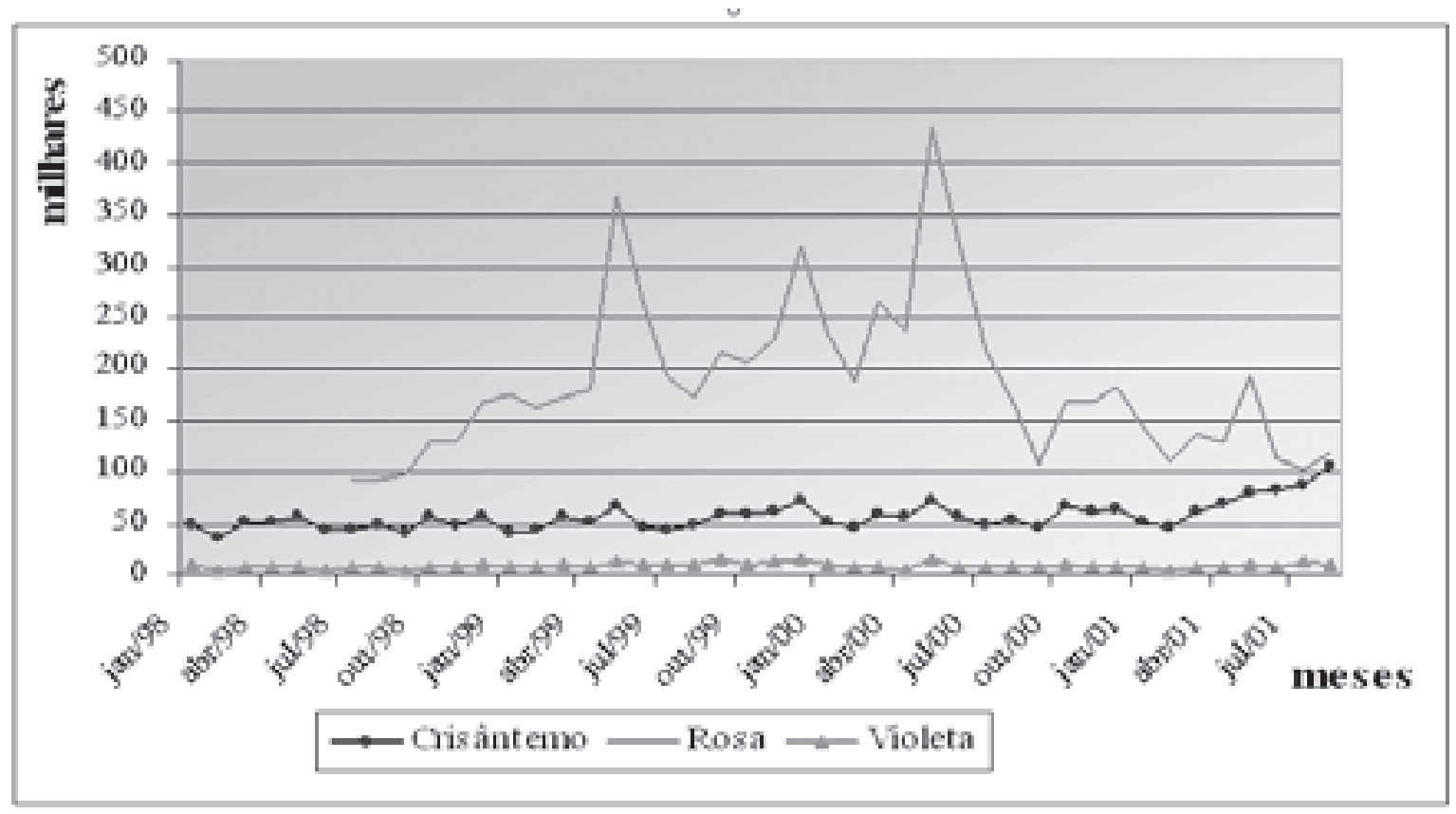

Figura 5. Volumes comercializados de rosas (em dúzias), crisântemos (em maços) e violetas (em caixas), na CEASA-Campinas, em períodos variados. 


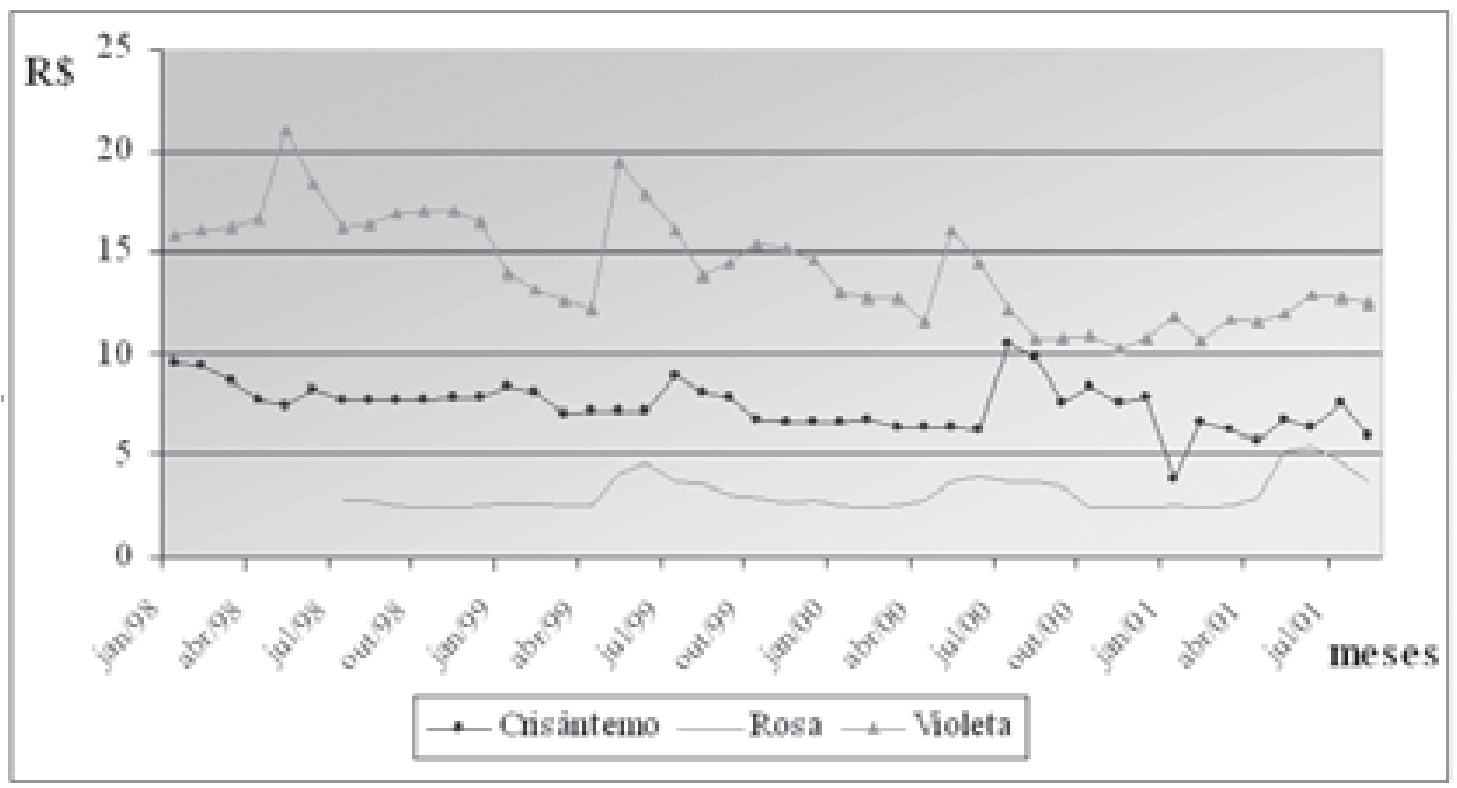

Figura 6. Preços adotados para rosas (por dúzia), crisântemos (por maço) e violetas (por caixa) na CEASACampinas, em períodos variados.

Para todos os produtos, maio e dezembro demonstraram alta oferta, sendo a violeta o produto muito ofertado também em outubro e março. Mesmo com produções possíveis durante todo o ano, os produtos ainda seguem a demanda do consumidor, mediante a presença de datas comerciais no calendário. As violetas ainda mostram maior regularidade na procura.

Quanto aos preços, as rosas observam aumentos em maio e junho. Para os crisântemos, julho tem aumentos provavelmente pela baixa oferta do produto no mês. Já para as violetas, a maior regularidade de oferta reflete a maior regularidade de preços, observando aumentos somente em maio.

\subsubsection{Comparação entre entrepostos}

Os tipos de comportamento das variações dos volumes comercializados em cada entreposto foram distintos, em função dos próprios níveis diferenciados de quantidades movimentadas em cada entreposto, assim como dos períodos distintos das séries de dados disponibilizadas.

Na CEAGESP-SP, o volume de rosas e crisântemos possui período de pico de 6 em 6 meses, enquanto o de violetas é de $3 \mathrm{em} 3$ meses. O volume de rosas e violetas no Veiling Holambra possui período de 3 meses e o de crisântemos, de 12 meses. Na CEASA-Campinas, o volume de rosas e crisântemos tem período de 6 meses e de violetas (apesar de não significativo), de 11 meses.
Quanto aos preços, os períodos encontrados foram iguais a 6 meses para todos os entrepostos, com exceção do preço de crisântemos na CEASA-Campinas, que foi igual a 3 meses (porém não significativo). Os preços no Veiling Holambra são os mais baixos, provavelmente em virtude do grande volume de comercialização e do sistema de formação de preços adotado pelo entreposto.

\subsection{Comparação entre os produtos nos diferen- tes entrepostos e seus padrões sazonais}

\subsubsection{Rosas}

O volume de rosas observou período de 6 meses na CEAGESP-SP e na CEASA-Campinas, ao passo que, no Veiling Holambra, o período foi de 3 meses, sinalizando a ocorrência de intervalos menores entre picos e, dessa forma, maior regularidade de oferta que nos outros entrepostos.

O período 12 foi encontrado para os preços praticados para rosas nos três entrepostos, isto é, existem picos de preços de 12 em 12 meses em cada um deles. Em maio, junho e julho, verificaram-se os preços mais altos para esse produto em todos os entrepostos.

A movimentação realizada no instante $t$ depende basicamente da movimentação do mês anterior e do período sazonal de cada produto em diferentes entrepostos, a não ser pelo volume de rosas da CEAGESP-SP, que depende também da movimentação de 4 meses anteriores a $t$. 
Já os preços dependem do mês anterior e do mesmo mês no ano anterior, porém os preços de rosas na CEASA-Campinas também têm uma ligação com os de 3 meses anteriores.

As Figuras 7 e 8 mostram, respectivamente, a movimentação e os preços de rosas na CEAGESP-SP, CEASA-Campinas e Veiling Holambra. Nota-se que o volume comercializado no Veiling Holambra é muito superior aos outros dois entrepostos, que mantêm o mesmo patamar de movimentação de rosas. Quanto aos preços, as rosas comercializadas no Veiling Holambra possuem os mais baixos, enquanto na CEAGESP-SP atingem os mais altos. Pode-se notar, também, que as oscilações durante o ano parecem similares nos três mercados.

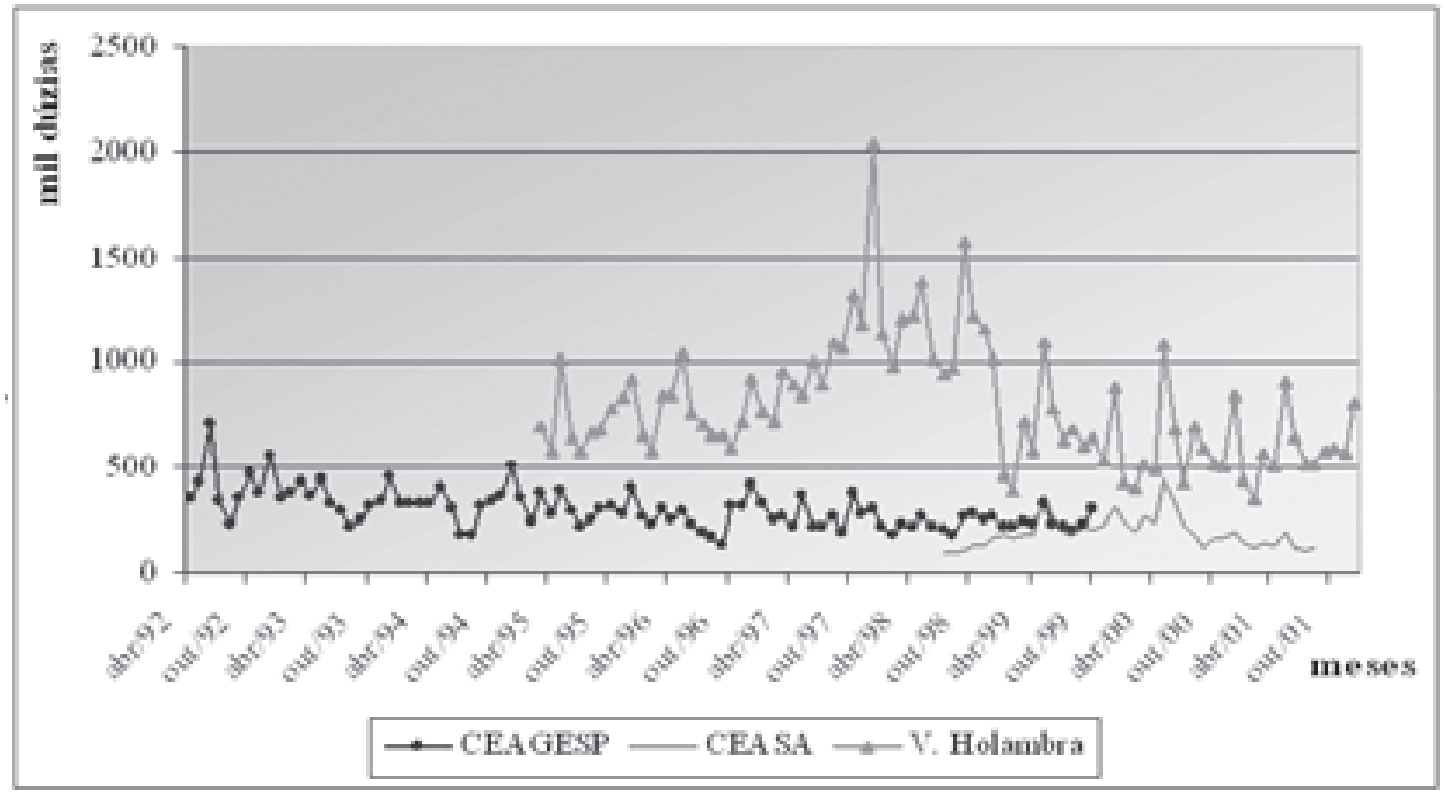

Figura 7. Volume de rosas comercializadas, mensalmente, na CEAGESP-SP, na CEASA-Campinas e no Veiling Holambra, em diferentes períodos.

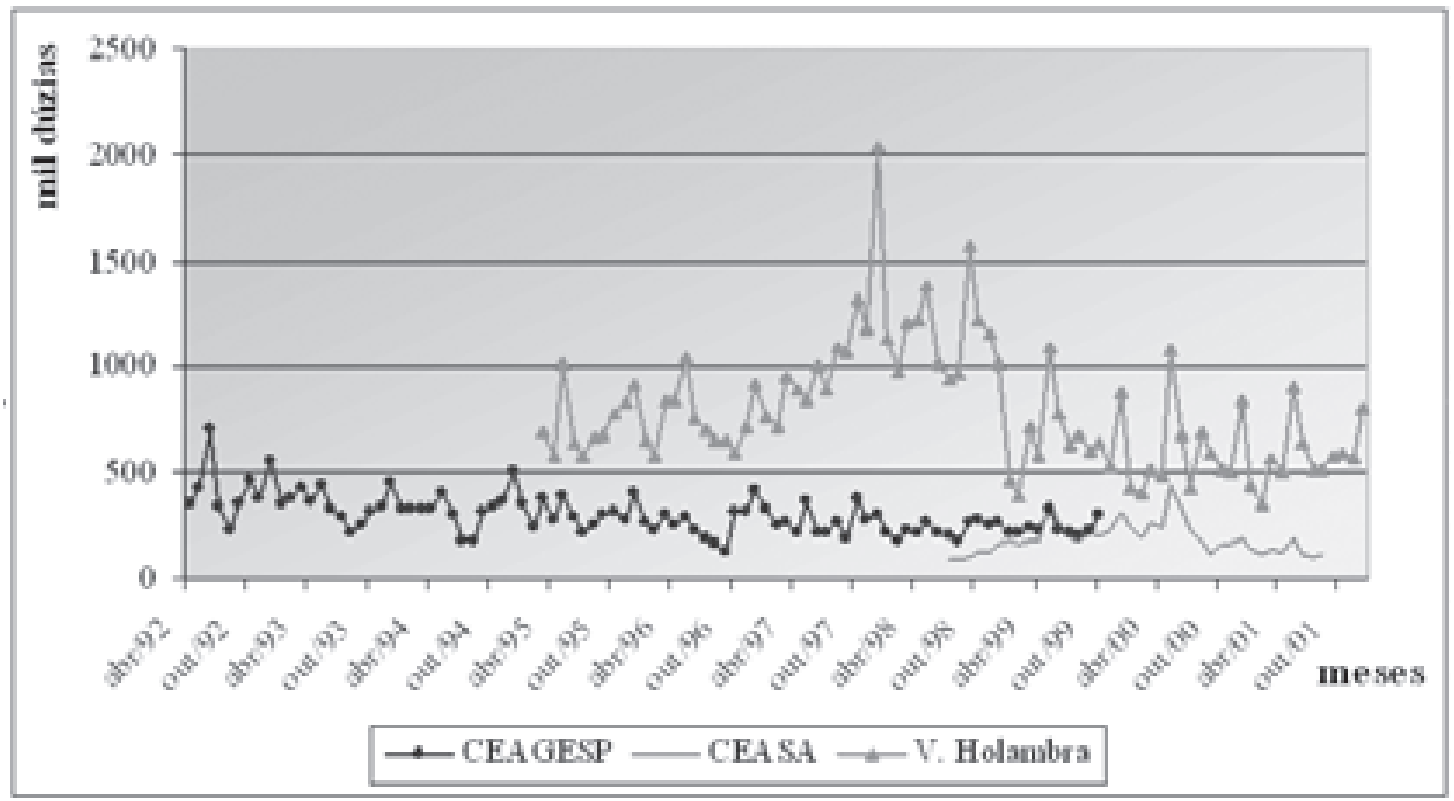

Figura 8. Preços praticados para rosas (por dúzia), mensalmente, na CEAGESP-SP, na CEASA-Campinas e no Veiling Holambra, em períodos distintos. 


\subsubsection{Crisântemos}

$\mathrm{O}$ volume de crisântemos tem período diferenciado em cada entreposto. Para a CEAGESP-SP e a CEASA-Campinas, encontrou-se o de 6 meses, enquanto para o Veiling Holambra o período foi de 12 meses.

As Figuras 9 e 10 ilustram o comportamento dos crisântemos nos diferentes entrepostos. O CEAGESPSP e o Veiling Holambra revelam níveis de volume al- tos, superando o volume comercializado na CEAGESPSP o volume do Veiling Holambra em 1997 e 1998. Maio e outubro demonstram picos importantes para todos os entrepostos, além de dezembro para a CEAGESP-SP e CEASA-Campinas e, março, para a CEASA-Campinas. Quanto aos preços, na CEAGESPSP foram praticados os mais altos, e no Veiling Holambra, os mais baixos.

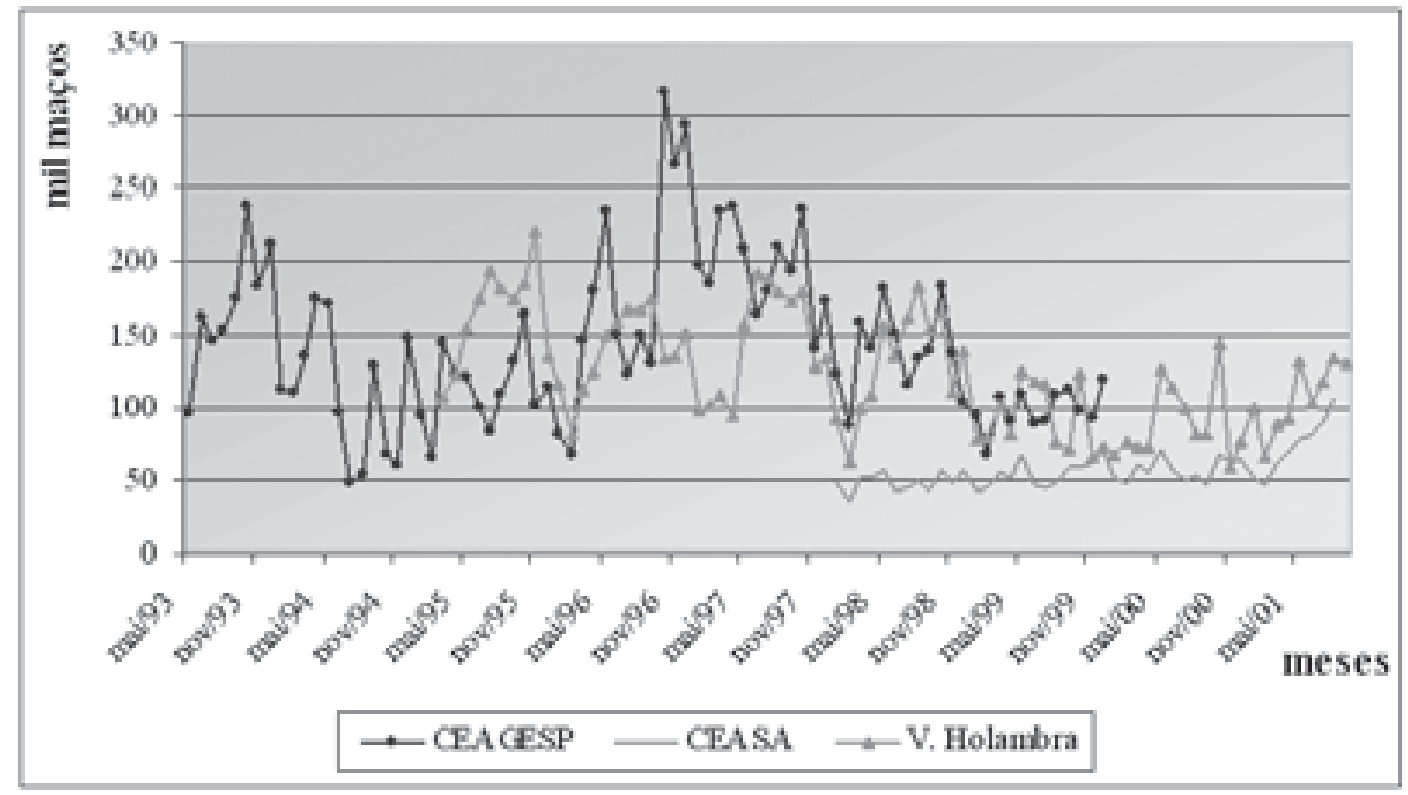

Figura 9. Volume de crisântemos (em maços) comercializados, mensalmente, na CEAGESP-SP, na CEASACampinas e no Veiling Holambra, em diferentes períodos.

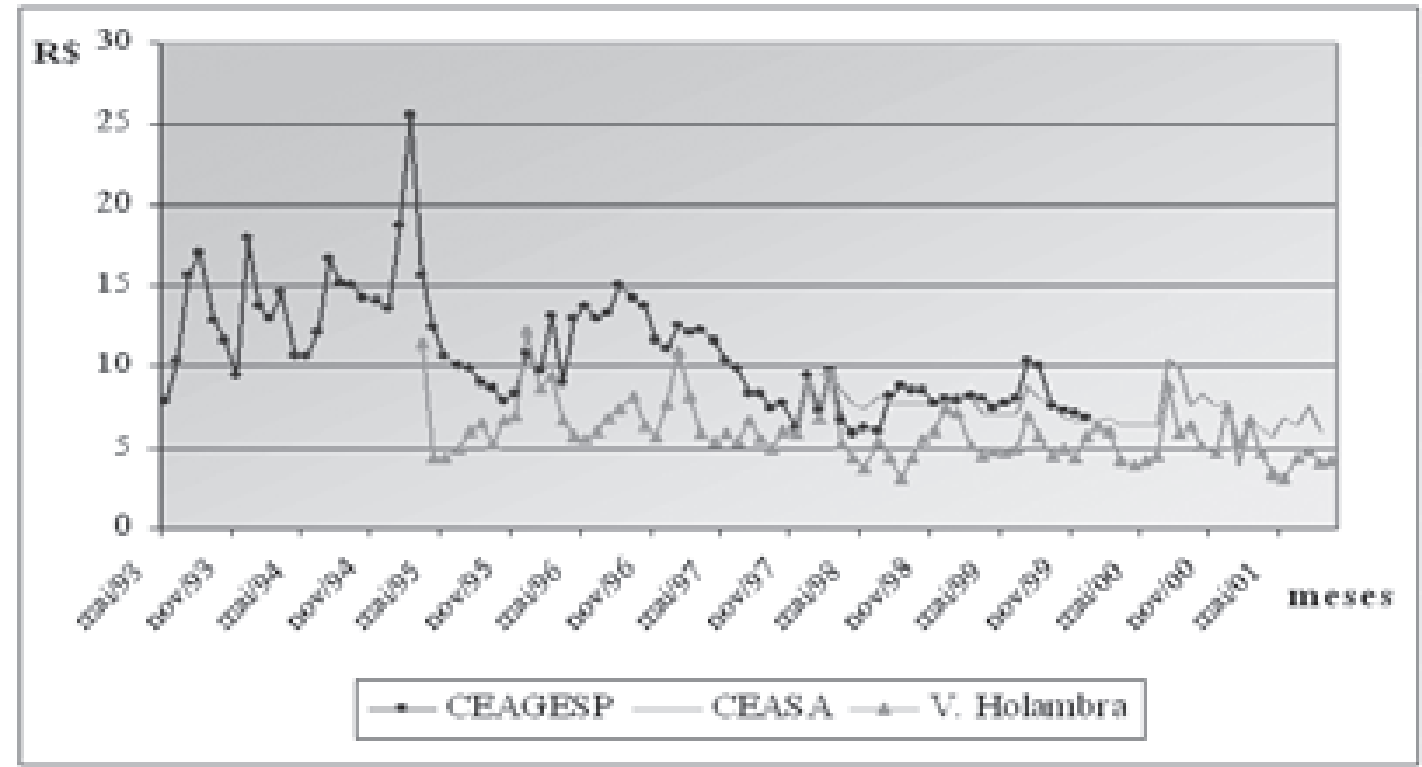

Figura 10. Preços praticados para crisântemos (por maço), mensalmente, na CEAGESP-SP, na CEASA-Campinas e no Veiling Holambra, em períodos distintos. 
O período de 6 meses foi encontrado para os preços praticados para crisântemos na CEAGESP-SP e no Veiling. No mercado de flores da CEASA-Campinas, identificou-se período de 3 meses, que, entretanto, em função do número de observações da série, não pode ser considerado significativo.

$\mathrm{O}$ volume comercializado em determinado instante $t$ tem ligação direta com o volume comercializado no mês imediatamente anterior, assim como ocorre a mesma influência na formação de preços. Outro fator importante é a dependência de acordo com a época do ano, ou seja, o período é diretamente relacionado aos acontecimentos do mercado.

\subsubsection{Violetas}

O volume de violetas é comercializado em grande escala e distribuído para diversos tipos de mercados consumidores, envolvendo desde supermercados a floriculturas. $\mathrm{O}$ volume comercializado de violetas foi semelhante na CEAGESP-SP e no Veiling Holambra, onde o período encontrado foi de três meses. Já para o volume da CEASA-Campinas, o período encontrado foi de onze meses, porém não significativo.

Os preços praticados para violetas se comportam igualmente nos três mercados, com período de seis meses. Vale ressaltar que a formação de preços depende basicamente do mês anterior e de seis meses anterio- res, ou seja, o período do ano é importante para a formação de preços.

O Veiling Holambra movimenta uma quantidade muito superior aos outros dois entrepostos, como se pode ver na Figura 11. Quanto aos preços, a Figura 12 indica que os do Veiling Holambra não atingem os mesmos níveis daqueles da CEAGESP-SP e da CEASA-Campinas.

\section{CONCLUSÕES}

As informações a respeito do período sazonal são de extrema importância ao sistema de comercialização de cada produto agrícola. Esse fato não é diferente para as flores e plantas ornamentais. Tanto produtores como consumidores podem beneficiar-se a partir do conhecimento do comportamento mais sistemático que seus produtos de interesse revelam.

A oferta mais regular de produtos no transcorrer do ano é objetivo importante não apenas para os consumidores, mas, também, para os produtores; no caso dos primeiros, eliminaria os períodos de escassez dos produtos, resultando em preços mais acessíveis, com menor amplitude de variação; no caso dos produtores, a oferta regular, em vez da busca por preços elevados na entressafra, resultaria em preços mais estáveis, tal como destacado em trabalho correlato de GATTI (1988).

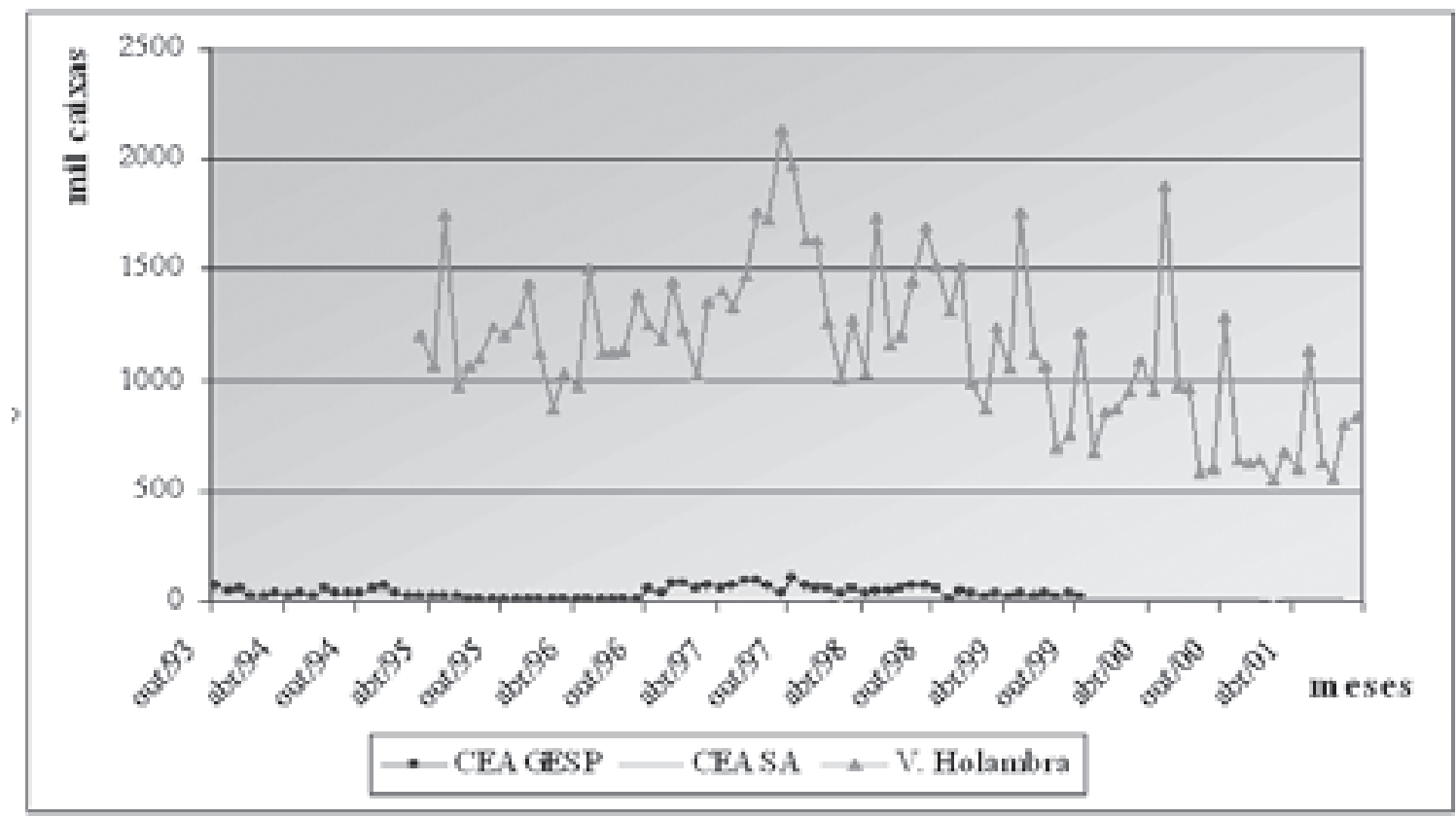

Figura 11. Volume de violetas (em caixas) comercializadas, mensalmente, na CEAGESP-SP, na CEASA-Campinas e no Veiling Holambra, em diferentes períodos. 


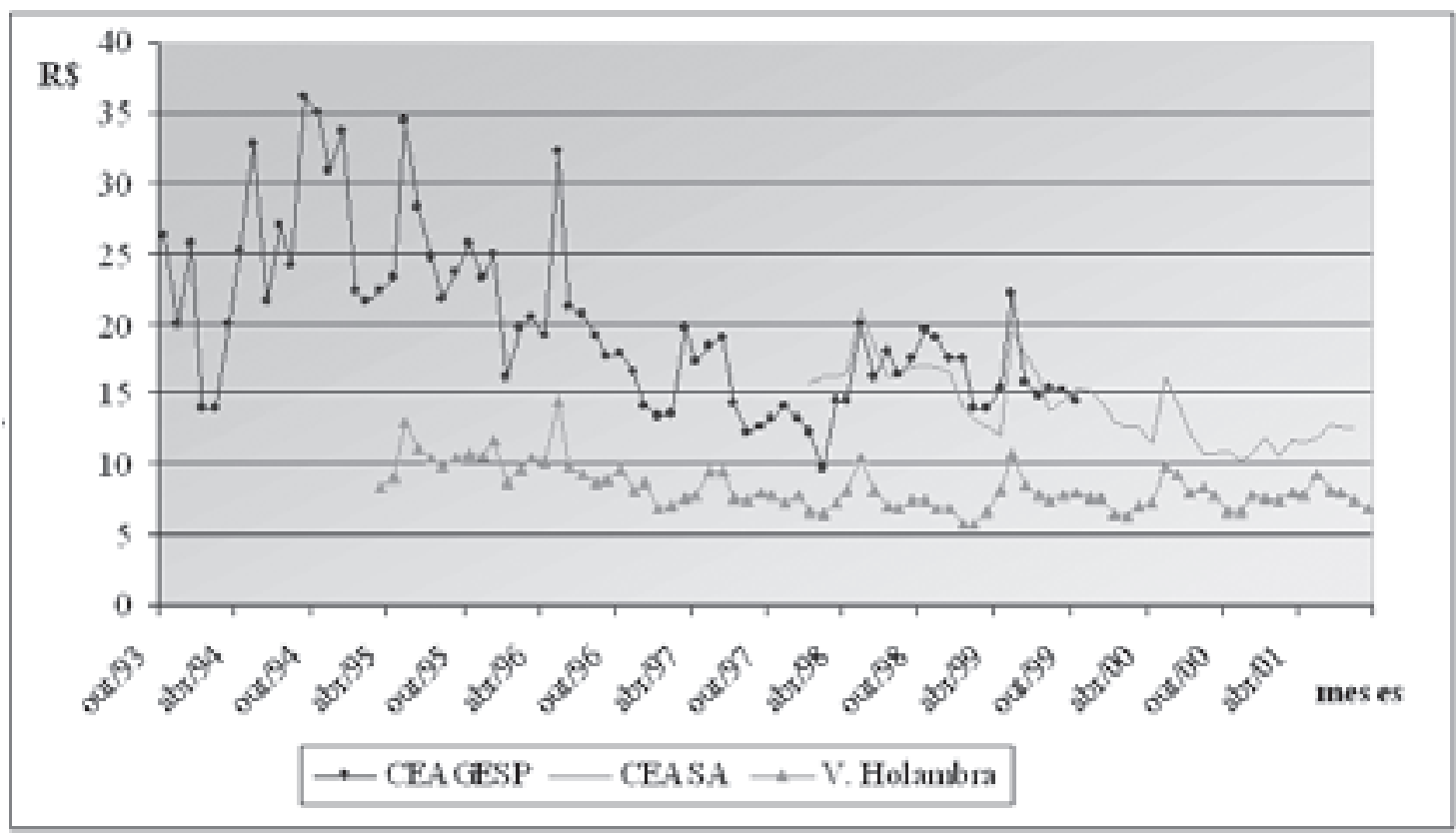

Figura 12. Preços praticados para violetas (por caixa), mensalmente, na CEAGESP-SP, na CEASA-Campinas e no Veiling Holambra, em períodos distintos.

Conhecendo os picos sazonais, o produtor pode organizar sua produção de forma a intercalar os maiores picos e, nesse sentido, conseguir sincronizar os picos de comercialização de maneira que estes ocorram várias vezes durante um ano. Aumentando os últimos durante um ano, a receita anual, conseqüentemente, aumentará e, ainda, poderá ser mais bem distribuída ao longo do ano. Lucros mais altos e mais regulares implicam segurança ao produtor, além de contribuírem para melhoria no sistema de produção, mediante benefícios como: maior regularidade de mão-de-obra empregada, maior gerenciamento de riscos, melhor controle de custos e implementação de novas tecnologias.

Rosas, crisântemos e violetas são passíveis de produção induzida em estufas e, portanto, sua oferta pode tornar-se mais regular se a demanda do consumidor brasileiro também aumentar sua regularidade. Além disso, o conhecimento do período, unido à disponibilidade de tecnologia viabilizando produções mais constantes, pode ampliar os negócios do produtor, aumentando, inclusive, suas exportações. Por exemplo, a partir do conhecimento dos picos de demanda em diferentes países do exterior, é possível intercalar ofertas tanto voltadas ao abastecimento interno quanto às exportações.

Dessa forma, o monocultor poderá beneficiar-se, avaliando a possibilidade de diversificação de sua produção. O produtor que já a vem diversificando usufrui- rá informações valiosas para tomar decisões estratégicas importantes para melhorar seu negócio.

Nesse sentido, os resultados apresentados e analisados nesta dissertação permitem a visualização de um efeito sazonal claro tanto nas séries de preços como nas de volumes comercializados das flores e plantas ornamentais selecionadas nos três principais entrepostos paulistas.

O volume comercializado de rosas na CEAGESPSP tem período 6 , o que significa que um ciclo se repete duas vezes durante um ano, ou seja, os picos que ocorrem com maior freqüência são os de 6 em 6 meses. Encontrou-se período 12 para os preços, porém esse pico não foi muito significativo, podendo demonstrar que tal série não possui, possivelmente, um comportamento periódico. No caso das rosas, os picos de volume, na CEAGESP-SP, revelam-se mais intensos em outubro, dezembro e maio. Isso se deve, talvez, respectivamente, ao Dia de Finados, às festas de final de ano como Natal e Ano Novo e ao Dia das Mães. Já para os preços, julho representa picos mais altos, sobretudo em função de uma oferta menor.

Quanto ao volume e aos preços praticados para crisântemos em maços, o período encontrado foi 6 . Esse volume se intensifica em maio, outubro e dezembro. O Dia das Mães explica o aumento de maio, assim como o de outubro pode ser explicado, prova- 
velmente, pelo Dia de Finados no início de novembro. As festas de final de ano demandam grande quantidade de flores, o que se repete com os crisântemos, cujos preços na CEAGESP-SP aumentam em dezembro e fevereiro, em função de alta demanda e baixa oferta respectivamente.

As violetas são mais comercializadas na CEAGESP-SP de 3 em 3 meses, isto é, encontrou-se período 3 para a série de volumes. Os preços das violetas mostraram-se significativos no período 6. Essas flores são muito consumidas para uso próprio, além de servir como presente em datas festivas do dia-a-dia do consumidor. Sua distribuição é mais regular ao longo do ano, porém há aumentos em março, maio, outubro e dezembro. Março aparece como uma nova data importante em função do Dia Internacional da Mulher e também por ser o mês de retorno das férias escolares.

$\mathrm{O}$ volume de rosas e violetas no Veiling Holambra possui período 3 e o de crisântemos, período 12, assim como a série de preços de rosas. Para os preços de crisântemos e violetas, o período é de 6 meses.

Nesse mercado, maio é um mês de intensa movimentação para rosas, crisântemos e violetas. Muito provavelmente devido, novamente, ao Dia das Mães e por ser também o Mês das Noivas. Mesmo com muita oferta, a alta demanda faz com que os preços sejam elevados. Outubro é responsável por grande comercialização de crisântemos para o Dia de Finados. Os preços de crisântemos tendem a cair após essa data, pois a oferta ainda está alta e a demanda diminui, apresentando, dezembro, significativa demanda de rosas e violetas. No entanto, as violetas ainda são mais procuradas durante o ano. Comercializadas em vasos, são também demandadas para uso próprio, observando então mais picos durante o ano, como em março e outubro.

Na CEASA-Campinas, para rosas e crisântemos, o período encontrado foi de 6 meses e, para violetas, 11 meses, apesar de não significativo. Essa não-significância pode sugerir que tal série de dados não seja periódica. Já para os preços, o período para rosas foi de 12 meses, para crisântemos 3 meses e, para as violetas, de 6 meses. O preço de crisântemos também apresentou período não significativo, indicando problemas na detecção do período.

Para todos os produtos, maio e dezembro demonstraram alta oferta na CEASA-Campinas, sendo a violeta o produto muito ofertado também em outubro e março. Mesmo com produções possíveis durante todo o ano, os produtos ainda são muito influenciados pela deman- da do consumidor mediante a presença de datas comerciais no calendário. As violetas ainda mostram maior regularidade na procura, pelo aumento de oferta, baixa de preços e demanda do consumidor também para uso próprio.

Quanto aos preços, as rosas comercializadas na CEASA-Campinas aumentam em maio e junho, devido, provavelmente, ao Dia das Mães e ao Dia dos Namorados, confirmando o hábito mais disseminado de comprar rosas para presentear. Para os crisântemos, julho tem aumentos provavelmente devidos à baixa oferta do produto. Já para as violetas, a maior regularidade de oferta reflete a maior regularidade de preços, com aumentos somente em maio, quando a demanda excede a oferta do produto.

Analisando esses resultados, pôde-se identificar algumas semelhanças entre flores e entrepostos.

O período 12 foi encontrado para os preços praticados para rosas nos três entrepostos, isto é, existem picos de preços de 12 em 12 meses em cada um deles. Maio, junho e julho são responsáveis por preços mais altos praticados para este produto em todos os entrepostos. O mesmo ocorreu para os preços praticados para violetas, que se comportam igualmente nos três mercados, com período de 6 meses. Em crisântemos, o período encontrado foi de 6 meses para a CEAGESP-SP e para o Veiling Holambra, sendo não significativo para a CEASA-Campinas.

Como a formação de preços não depende exclusivamente do entreposto e, sim, de muitos fatores de mercado, é natural que o mesmo produto obtenha os mesmos períodos em diferentes entrepostos. Além disso, os entrepostos em questão fazem parte de um mesmo Estado, sendo separados por distâncias relativamente curtas, o que faz com que os picos de preços ocorram em períodos semelhantes, o que não se dá com os períodos detectados para o volume comercializado dos mesmos produtos nos três entrepostos.

Algumas dificuldades foram enfrentadas no decorrer da pesquisa, principalmente na coleta de dados. $\mathrm{O}$ sistema de coleta de cada entreposto opera de forma diferenciada ou, ainda, a coleta vem ocorrendo de forma irregular, ou seja, dados são omitidos entre um período e outro, tal como observado na CEAGESP-SP. Já na CEASA-Campinas, os dados foram tabulados somente a partir de 1998, o que limita bastante a abrangência da série a ser trabalhada. Outra questão ainda a considerar é o fato de que os dados muitas vezes são parcialmente disponibilizados a pesquisadores, 
por motivo de manutenção do sigilo de informações, que, no caso do Veiling Holambra, por exemplo, exerce importância significativa no seu planejamento estratégico.

Em termos de recomendações para trabalhos futuros, novas tentativas devem ser realizadas visando à obtenção de outras séries de dados que envolvam outras flores e plantas ornamentais, eventualmente em períodos mais abrangentes, ou ainda incluir modelos de intervenção que ressalvem acontecimentos de natureza estrutural nas séries, como choques econômicos, pragas, mudanças de hábito etc.

\section{REFERÊNCIAS BIBLIOGRÁFICAS}

ALBERTINI, M.R.; VIEIRA, D.P. \& BASETTO, E. Variação no volume de entrada de flores nas principais datas festivas na Ceagesp, (compact disc). In: SIMPÓSIO DE INICIAÇÃO CIENTÍFICA DA UNIVERSIDADE DE SÃO PAULO, 7., Resumos... São Paulo, 1999.

ALMEIDA, F.R. de F. \& AKI, A.Y. Grande crescimento no mercado de flores. Agroanalysis, v.15, n.9, p.8-11, 1995.

ALONSO, A; ALVAREZ PINTO, M. \& VEJA, J. Revisión bibliográfica: horticultura ornamental: ciencia y arte. Cultivos Tropicales, v.18, n.2, p.31-39, 1997.

ANDERSON, O.D. Time series analysis and forecasting: the Box-Jenkins approach. Great Britain: Butterworth, 1976. 182p.

ARRUDA, S.T.; OLIVETTE, M.P.A. \& CASTRO, C.E.F. Diagnóstico da floricultura do Estado de São Paulo. Revista Brasileira de Horticultura Ornamental, v.2, n.2, p.1-18, 1996.

BARLETTA, A. Stimulating demand for flowers in Brazil. FloraCulture International, p.38-39, 1995.

BOLETIM MENSAL CEAGESP, São Paulo: CEAGESP, 1992-2001.

BONGERS, F. A serviço das flores. Agroanalysis, v.21, n.8, p.32-34, 2001.

BOX, G.E.P. \& JENKINS, G.M. Time series analysis: forecasting and control. San Francisco: Holden-day, 1976. $375 \mathrm{p}$.

BOX, G.E.P.; JENKINS, G.M. \& REINSEL, G. Time series analysis: forecasting and control. New Jersey: Prentice Hall/Englewoods Cliffs, 1994. 598p.

CASTRO, C.E.F. Armazenamento. Casa da Agricultura, v.7, n.4, p.18-21, 1985.

CASTRO, C.E.F. Cadeia produtiva de flores e plantas ornamentais. Revista Brasileira de Horticultura Ornamental, v.4, $\mathrm{n}^{\mathrm{os}} 1 / 2, \mathrm{p} .1-46,1998$.
CHONMALUCK, W. Analysis of the Netherlands' import demand for tropical cut-flower orchids: Thailand. Kasetrart Univ., Bangkok, Thailand, 1996. 83p. (Graduate School),

CLARO, D.P. Análise do complexo agroindustrial das flores no Brasil. Lavras, Universidade Federal de Lavras. 1998. 103p. Dissertação Mestrado.

CLARO, D.P. \& OLIVEIRA, P.B. de. A comercialização de flores na Ceasa-Campinas e no Veiling Holambra. Revista Brasileira de Horticultura Ornamental, v.5, n.1, p. 70-77, 1999.

GATTI, E.U. A evolução recente do setor de flores e plantas ornamentais no Brasil. Agricultura em São Paulo, v.35, p.123-147, 1988.

GRANGER, C.W.J. Seasonality: causation, interpretation and implications. In: ZELLNER, A. (Ed.) Seasonal analysis of economic time series. Washington: Department of Commerce, Bureau of the Census, 1978. p.33-46. (Economic Research report, 1)

GROOT, N.S.P. de. Floriculture worldwide trade and consumption patterns. Acta Horticulturae, n.495, p.101121, 1999. Apresentado ao World Conference on Horticultural Research, Rome, 1998.

JENKINS, G.M. Practical experiences with modelling and forecasting time series. St. Helier: Gwilyum Jenkins and Partners, 1979. 146p.

KÄMPF, E.; BAJAK, E. \& JANK, M.S. O Brasil no mercado internacional de flores e plantas ornamentais. Informe GEP/DESR, v.3, n.3, p.3-11, 1990.

KIYUNA, I. Flores. Prognóstico Agrícola, v.2, p.189-194, 1998.

KONO, Y. Relation between market value and mechanism of price formation of cut flowers. Bulletin of the Kyushu National Agricultural and Experiment Station, n. 32, p. 51-73, 1997.

KRAS, J. Marketing of cut flowers in the future. Acta Horticulturae, n.482, p.401-405, 1999. Apresentado ao International Symposium of Cut Flowers in the Tropics, Bogota, 1998.

LESZCZYÑSKA-BORYS, H. \& BORYS, M.W. Reflexiones sobre los recursos genéticos de México para la industria hortícola ornamental. Revista Chapingo, v.1, n.1, p.171183, 1994.

MARQUES, R.W. da C. Avaliação da sazonalidade do mercado de flores e plantas ornamentais no Estado de São Paulo. Piracicaba, 2002. 114p. Dissertação (Mestrado) Escola Superior de Agricultura "Luiz de Queiroz", Universidade de São Paulo. 
MARQUES, R.W. da C. \& CAIXETA FILHO, J.V. Mercado de flores e plantas ornamentais no Estado de São Paulo: avaliação da sazonalidade no Veiling Holambra. Revista Agricultura em São Paulo, v. 49(2), 2002a. p.31-54.

MARQUES, R.W. da C. \& CAIXETA FILHO, J.V. Sazonalidade do mercado de flores e plantas ornamentais no Estado de São Paulo: o caso da Ceagesp-SP. Revista de Economia e Sociologia Rural, v.40, n.4, 2002 b. p.789-806.

MATSUNAGA, M. Potencial da floricultura brasileira. Agroanalysis, v.15, n.9, p.56, 1995.

NELSON, C.R. Applied time series analysis for managerial forecasting. San Francisco: Holden-day, 1973. 386p.

OLIVEIRA, M.J.G. de. Logística de pós-colheita de rosas. Revista Brasileira de Horticultura Ornamental, v.1, n.2, p.101-107, 1995.

PIERCE, D.A. A survey of recent developments in seasonal adjustment. The American Statician, v.34, n.3, p.125134, 1980.
PINO, F.A.; FRANCISCO, V.L.F. dos S.; CÉZAR, S.A.G. et al. Sazonalidade em séries temporais econômicas: um levantamento sobre o estado da arte. Agricultura em São Paulo, v.41, n.3, p.103-133, 1994.

SALUNKHE, D.K.; BHAT, N.R. \& DESAI, B.B. Postharvest Biotechnology of Flowers and Ornamental Plants. Germany: Springer-Verlag, 1990. 183p.

SANTIAGO, M.M.D.; CAMARGO, M. de L.B. \& MARGARIDO, M.A. Detecção e análise de outliers em séries temporais de índices de preços agrícolas no Estado de São Paulo. Agricultura em São Paulo, v.43, n.2, p.89-115, 1996.

SAS INSTITUTE: Release 8 (software). Cary, 1999.

SONEGO, G. \& BRACKMANN, A. Conservação pós-colheita de flores. Ciência Rural, v.25, n.3, p.473-479, 1995.

TAKIZAWA, M. Demand function analysis of ornamental plants on the wholesale market in Tokyo. Bulletin of the Tokyo Metropolitan Agricultural Experiment Station, n.22, p.73-80, 1990. 